\title{
LINGUISTICS
}

DOI:

\section{SEMANTIC REALIZATION OF THE LEXEME “KPACOTA” IN THE SYSTEM OF V. SOLOVYOV'S POETRY}

\author{
Simona Korycankova \\ Assoc. Prof. PhDr. Mgr., Ph.D. \\ Masaryk University \\ (Brno, Czech Republic) \\ e-mail: korycankova@ped.muni.cz
}

\begin{abstract}
The aesthetic-philosophical category of beauty is also researched by linguists. Based on Vladimir Solovyov's philosophical system, one may assert that the perception of beauty plays an important role, not just in the poet's worldview, but in his literary work as well. The images of beauty that we analyze in Solovyov's poetry are built upon a specific set of words, a lexico-semantic analysis of which reveals their author-specific use. The contextual setting of such images is accompanied by a semantic property matching the poet's aesthetic and philosophical ideas, e.g., Красота, луч, свобода, любить, пурпурный, святой and оthers. Тhe semantic shifts in the use of the word красота illustrate the nuances of meaning typical for the actualization of the philosophical idea of beauty, its semantic refinement that accentuates the associative links to the emanations of the high beauty of the divine world. The poem "The Nocturnal Voyage" served as a sample for the analysis, the main component of its content based upon the salvation of the Suffering Beauty by the hero of the poem. Thus, a lyrical -epic basis is combined with a verbal makeup that helps illuminate the images of light, color, sound and emotional impressions of the ideal Divine world, i.e., the world of perfect aesthetic saturation - the world of beauty.
\end{abstract}

Keywords: poetry, text, analysis, image, beauty, cognizance

\section{СЕМАНТИЧЕСКАЯ РЕАЛИЗАЦИЯ ЛЕКСЕМЫ «КРАСОТА» В СИСТЕМЕ ПОЭТИЧЕСКОГО ТВОРЧЕСТВА В. СОЛОВЬЕВА}

\author{
Симона Корычанкова \\ Doc. PhDr. Mgr., Ph.D. \\ Университет им. Масарика \\ (Брно, Чешская Республика) \\ e-mail: korycankova@ped.muni.cz
}

\begin{abstract}
Аннотация.Эстетико-философская категория красоты исследуется также учеными-лингвистами. Опираясь на философскую системуВладимира Соловьева, можно утверждать, что восприятие красоты имеет важное место не только в мировоззренческих представлениях поэта, но также в его литературной работе. Образы красоты, которые мы анализируемв поэтическом творчестве Соловьева, построены на специфическом наборе слов, лексико-семантический анализ которых указывает на их индивидуально-авторское употребление. Контекстуальное оформление таких образов сопровождается семантической характеристикой, соответствующей эстетико-философским представлениям поэта, напр.Красота, луч, свобода, любить,nурпурный, святой и др. Семантические сдвиги в употреблении слова «красота» наглядно показывают те нюансы значения, которые характерны для актуализации философской идеи красоты, ее смыслового уточнения, акцентирующего ассоциативные связи с эманациями высшей красоты божественного мира. Примером для анализа послужило стихотворение «Ночное плавание», в котором основной компонент содержания выстроен на спасении Красотыстрадалицы лирическим героем. Так сочетается лирико-эпическая основа с вербальным оформлением, способствующим раскрытию образов света, цвета, звука и эмоциональных восприятий Горнего идеального божественного мира, т.е. мира идеальной эстетической насыщенности - мира красоты.
\end{abstract}

Ключевые слова: поэзия, текст, анализ, образ, красота, осмысление

INTRODUCTION. Beauty as perceived by Vladimir Solovyov is deified and mysterious, it is the principle through which one attains a direct connection to the foundation of existence. Without beauty, there is no transformed matter, i.e., no global spiritual refinement of creation. "Beauty, or an idea given flesh, is the best half of the real world, the half that not only exists, but deserves existence. An idea, in general, is a thing that, by itself, is worthy of being" (Solovyov, 1994). This implies that the aim of beauty is to transform reality, it must not merely be a surface coating, but penetrate the essence of each object and event. Clearly, "true beauty, not as a mere reflection of an idea from matter, but its true presence in matter, presupposes, above all, the deepest and closest interaction between the internal, or spiritual, and external, or material, existence. That is the main properly aesthetic precept" (Solovyov, 1994). V. Solovyov's contribution to the Russian aesthetic thought is embodied in his poetry, which is based on a mystic and philosophical understanding of the world and inspired by the idea of true beauty incarnated.

LITERARY OVERVIEW.The ethical and aesthetic framework of V. Solovyov's worldview is intertwined with the mystic and religious source of his philosophy. The thinker had dreamed of a philosophical treatise on his ideas of beauty and the meaning of art, however, he only had time to finish two principal articles where he analyzes the meaning of aesthetics in the universal process of creation. It is known that "in the early 80 's, Solovyov envisioned "The Aesthetics" as free theurgy: art had to have a connection to church mysteries and a mystic foundation. Aesthetics as theurgy was the 
third part of his religious and philosophical system, a capstone for theocracy and theosophy" (Mochulsky, 2000). However, it was only in the late 80 's that Solovyov returned to aesthetic matters and published two articles, "Beauty in nature" (1889) and "The general meaning of art" (1890). The magnum opus on aesthetics was assumed to have been prepared for print, but was never published or recovered after the thinker's death. K. V. Mochulsky claims that it was never even written, and that "the author merely intended to revise and order his earlier articles on aesthetic matters. In the ten years of church and community work, Solovyov's views underwent a significant change, leaving little of the 80 's vision" (Mochulsky 2000). As it is, one can avail oneself of five articles when analyzing V. Solovyov's aesthetic ideas: "Beauty in nature", "The general meaning of art", "On lyrical poetry", "The first step toward positive aesthetics", "The philosophical beginnings of holistic knowledge."

RESEARCH METHODS.The lexeme кpacoma in the sense of the highest principle of creation is used by Solovyov in the poem "The Nocturnal Voyage” («Ночное плавание»), which is a free translation of H. Heine's "Gods of Greece". For his translations, Solovyov always chose poems that reflected his philosophical worldview and matched his spiritual mood. All poetic translations by Solovyov can be asserted to have been reimagined in accordance with his personal worldview. In the present poem, Solovyov focuses on the hero who saves the Suffering Beauty imprisoned in the earthly world. Beauty is understood here by Solovyov as a symbol of the dawning cognizance of the world's spiritual creation; it, like the eternal feminine principle, descends to earth from heavenly dimensions and, having been shackled, is saved by a human hero, i.e., a symbolic union of heaven and earth takes place. Building upon Heine's idea, Solovyov perceives Beauty as the eternal feminine principle that is the means to All-Unity. Beauty merges with the hero that liberates her ( $\mathrm{Mb} \mathrm{на} \mathrm{берег} \mathrm{вылили} \mathrm{вдвоем),} \mathrm{thus} \mathrm{actualizing} \mathrm{the} \mathrm{emergence} \mathrm{of} \mathrm{a} \mathrm{new} \mathrm{being,} \mathrm{reborn} \mathrm{in} \mathrm{accordance} \mathrm{with}$ the holistic principle of existence. The lexical means used to create an image of the transformed entity contain semantic elements of light (солние, лучом), color (пурпурным), sound (тихо). The dynamics of the image are conveyed by the poet by means of a lexico-semantic realization of visual and auditory perception, augmented by verbs associated with smooth, unhurried movement (всходило, играя, причалил, вылили).

Уж солнце всходило, по зыби морской

Играя пурпурным лучом.

И к пристани тихо причалил наш челн.

Мы на берег вышли вдвоем.

("The Nocturnal Voyage")

The dynamics of the poem are built upon antithetic images realized through key expressions that allow the author to counterpose pictures of a rising sea's elemental power (Волнуетсяморе, иветерревет...) and its calm state, conveyed by means of an associative link to the meaning of the expressions тихоотчалил, всплеснулаволна, тихопричалил. The meaning of the opposed figurative expressions is complicated by the addition of the author's personalized semantics of the expressions вздымалося море - сходилися волнь - волнуется море - всплеснула волна exposing the activity of the watery element, its power and mutability. Solovyov actualizes the idea of primal chaos: "The movement of living elemental forces in nature has two main shades: those of free play and terrible struggle. The same natural phenomenon, a thunderstorm, can represent either shade, depending on the circumstances under which it happens. The majestic beauty of summer storms, like that of a turbulent sea, depends on the moving chaos and the excited intensity of the elemental forces vying with the luminous world order for ultimate supermacy" (Solovyov 1994).

Chaos, or perfect formlessness, is the necessary foundation of any manifested beauty. Such a perception of Beauty's materialization is verbalized by means of lexemes with the meaning of the element of water in semantic and syntactic connection with verbs of movement that bear the main message, which allows to isolate philosophically important ideas in the poem's context that define the structure of the writer's artistic world. Thus, the poet conveys the idea of saving the Suffering Beauty, which is actualized not only in the narrow sense of a personification of beauty manifested on the earthly plane, but also in the sense of the mystic feminine principle, the foundation of ideal existence that melds the Divine and the Mundane in All-Unity.

An important signifying element that helps realize the author's creative intent is the acoustic property, which, if emphasized, contributes to the actualization of the auditory perception of the poetic image through key lexemes with the meaning of sound - тихо, звучали, речь, говорила, крик, ревет. The use of the antonymic associative pairing тихо$к р и к$ adds a dynamic property to the acoustic styling of the poem, which is marked in the first quatrain (Om береza тихо отчалил наш челн), sharply changed and reinforced in the fourth quatrain (Вдруг ввышине / Пронесся пронзительны йкрик), further developed in the fifth quatrain (тот крик нам грозил) and culminates in a qualitatively new feeling of silence (тихо причалил) and tranquility (Мы на берег вылили вдвоем) in the last quatrain.

The poem is permeated with the spirit of an otherworldly, mystic reality, actualized by means of words and expressions - бледная тень, она (луна), волшебный серебренный блеск, бред, мгла да туман, чудится, тайною; ни в явь, ни во сне; нездешней, греза, призрак, создание мысли больной. Images of the otherworld are tightly bound to images of the hero's emotional state verbalized by means of the lexemes уныло, тоскливо, плачуший, вздрогнули, зловещего, злобно, страшит, люблю аnd others. Such a number of expressions used to describe the otherworldly reality depicted by the author signifies a deliberate use of the counterposed images device, where the lexeme Kpacoma, associated with the earthly reality (Вневоле, в тяжельх иепях Красота), gains personalized meanings and forms an antonymic associate to the images of the surreal, mystic plane.

This approach allows Solovyov to emphasize the image of Beauty, which, saved and reborn in the otherworld, in the photic, chromatc and auditory properties of the divine world (солнце, пурпурнымлучом, тихо), merges with the 
hero that protected her. The image of the ultimate unity of the female (Красота, Страдалица) and male ( $\Omega$ ) stands out in the foreground of this world's dimensions actualized by means of lexemes - страсти, скорби, горе, муки, злобаsemantically connected to manifestations of man in the Mundane and associated with earthly experiences. The image of earthly emotions is built upon an explicit semantic interconnection of the lexemes страсти, скорби, горе, муки, злоба that, in the poem's context, are included within the semantic-associative borders of the expressions посланник небес-B груди заключиля своей.

The associative conjunction, in the reader's mind, of the linguistic means describing the hero is reinforced through the idea of the contradiction between the Mundane and Divine, suffering and bliss, ugliness and perfection. The dense emotional space is emphasized by the poet by the repetition of the lexeme все/всю, the meaning of which, as actualized by the author, not only refines the emotional connotation, but also summarizes the significant markers of earthly experiences for all mankind during its entire history (людей, веков).

Мне чудится, будто - посланникнебес -

Все страсти, все скорбилюдей,

Всегоре имуки, всюзлобувеков

В груди заключил я своей.

("The Nocturnal Voyage")

The beauty/love pairing, perceived aesthetically and philosophically, forms an indivisible poetic space of ideas and images, objectivized through the lexical nominates Kрасота and любовь/любить. The actualization of the idea of perfect Beauty and the image of its salvation through the highest love, which sacrifices the imperfection of the earthly principle, represent, in the author's artistic worldview, the explicit idea of the ethical and aesthetic foundation of the perfect world. The meaning is underlined through the repetition of the cognate lexemes любить, любовь, where, on the one hand, the development of the author's philosophical understanding of true love is emphasized, and, on the other hand, the dynamics of the image of the hero's emotional mood and his rebirth by means of this feeling and unification with the foundation of existence are achieved.

В неволе, в тяжелых цепях Красота,

Но час избавленья пробил.

Страдалица, слушай: люблю я тебя,

Люблю и от века любил.

Любовью нездешней люблю я тебя.

Тебе я свободу принес,..

("The Nocturnal Voyage")

The lexeme любить and любовь (люблю, любил, любовью) is repeated in the short fragment of the quoted poem five times, four of those in verb form, which proves the semantic significance that V. Solovyov lent to the image of an emotionally rich and intense amorous state of the hero. The energy and dynamism of the image of Beauty's salvation is explicitly emphasized by the use of the verb принес(дар) and the repetition of the lexeme смерть (смерти), semantically and associatively connected with the verb yмрешь. The poet's artistic worldview meets religious ideas of a deity's spiritual perfection, realized through death and rebirth.

The symbol of the captive Beauty (Вневоле, втяжельх цепях Красота) gains a personalized meaning realized through the contextual-associative image of goddess Beauty's descent into the Mundane (Лишь в смерти спасение падших богов) and her rebirth by means of death and resurrection (Умрешь и воскреснешь со мной). The poem emphasizes the author's actualization of the meaning of the word воскреснешь (сомной), refined by the expression сомной, which explicates Solovyov's idea of the savior-hero, an envoy of heaven, who, by bringing freedom to the Sufferer, dies with her and is reborn in the Divine. In L. Pild's opinion, Solovyov thus makes his translation closer, not to Heine's original, but to his own myth of the Eternal Femininity. "Solovyov's hero loves the Sufferer with an "otherworldly love" and saves her from the evil of the "earthly element", while, in Heine's original interpretation, "beauty is elusive, that is, man cannot always define its nature, its essence, or influence its manifestations" (Pild, 2007).

In his analysis of Solovyov's translation, N. V. Kotrelev claims that the Russian poet unconditionally interprets beauty as a feminine principle, thus adding his philosophical perception to the original text (Kotrelev, 2005). The lexeme Kpacomais capitalized by Solovyov, which formally reflects its significance as a symbol of beauty in explicit connection with the lexeme Страдалица. The internal associative semantic connection is born on the basis of a mysticphilosophical reading of the text, when the lexical pairing Красота-Страдалица is augmented by the associates Вечная женственность - св. София.

The analysis concludes that Solovyov not only evoked in himself the lyrical mood necessary for a good translation of a poem, but also elaborated the semantic structure of the original by incarnating the mystic-philosophical ideas of the place of the idea of Beauty in the creation of the material world and its connection to the feminine principle, which is postulated as an integral part of divinity. The hero of the poem addresses God with a prayer for salvation, and thus a direct figurative-spiritual interconnection of the nominate chain Страдалица-лирическийгерой - Kpacoma - Бог is demonstrated.

Но что это? Боже, спаси ты меня!

О, Боже великий, Шаддай!

Качнулся челнок, и всплеснула волна... 
Шаддай! о, Шаддай, Адонай!

("The Nocturnal Voyage")

In the context of the poem, the idea of the salvation of Beauty and the taming of elemental forces is actualized in the image of the calm sea that underlines the associative link with the subjugation of the chaotic elemental principle («Качнулся челнок, и всплеснула волна...») and the transition to the higher spiritual dimensions. Following Solovyov's aesthetic-philosophical ideas about the cognizance of the meaning of the universal idea in manifest Beauty and Goodness (Love), one can see in the poem a direct realization of man's irreplaceable role in the universal creative process. Man, aware of the divine foundation of existence, turns to the source - God (Шаддай, Адонай), and, with his help, leads the personified Suffering Beauty, a symbol of the earthly nature, out of the prison of formless chaos and the earthly element. Thus the Divine is united with the Mundane in the All-Unity of existence.

An elaboration of the image of the Divine's beauty can be traced in the poem "The Soul's Delight" («Восторгдуши»), where the aesthetic principle of the otherworld is accompanied by associated images of the auditory and emotional manifestation of the described space. In the poem's context, the hero (он) has felt the deity's touch (святая красота), however, captivated as he is by the mundane world (иумящий балаган), he fails to retain a belief in the eternity and perfection of the supra-material world (не тленная мечта) and falls completely under the Mundane's sway («И бледный призрак тихо отлетал»).

The idea of high beauty is explicated by means of the lexeme красота and the epithet святая, which connotes a property of the Divine. The contextual surroundings actualize the rich emotional and auditory earthly space of the hero, which is formally emphasized through a multiple antithesis (восторг души - расчетливь мобманом, речью рабскою - живой язык богов, святыню мирную - шумящим балаганом), where the chief semantic role is played by key lexemes (восторг, обман, речь, язык, святыня, балаган) along with epithets and contextually relevant words (души, расчетливым, рабскою, живой, богов, мирную, шумящим), which lend personalized properties to poetic expressions. Thus, the image of man's existence on earth (цумящий балаган) is characterized by the poet by means of a negative connotation with an unpleasant auditory sensation associated with an obstacle to the soul's ascension to the domain of the Divine.

The dynamics of the image are reinforced through the use of the dominants заменил, обманул, which carry the main message. The earthly space, strongly emphasized through imagery, is verbalized through lexemes (расчетливым обманом, речью рабскою, иумящим балаганом, земной пыли, злобный крик, коснеющие руки) associated with experiences of the Divine and an imprisonment in corporeal flesh. The intensity of the impact on the reader is refined by the use of participial and verb forms разбит, разочарован, прикован, заглушал, отлеталсontaining in their semantic property man's inability to withstand the power of material temptations.

Когда же сам, разбит, разочарован,

Тоскуя, вспомнил он святую красоту,

Бессильный ум, к земной пыли прикован,

Напрасно призывал нетленную мечту.

("The Soul's Delight")

RESULTS AND DISCUSSION. The emphasized property of the Mundane as the basic figurative cognizance of the poem is counterposed with the peaceful image of the Divine. All the expressions associated with the idea of the higher dimensions reduce their property to the idea of eternal beauty, whose central position is specified by the verbs вспомнить захотел. The hero is unable to revive the immortal dream in his memory, he misses love, yet the malicious scream of unbelief is silenced by captivating sounds that recall past feelings. The images demonstrated define the hero's personality, which contains as an inalienable part the emotional properties of the author's sensory perception, closely bound to the manifestation of the auditory property. Thus, associatively, the Mundane is connected not only with images of earthly shackles and suffering, but also loud (злобныйкрик) imperfect (речью рабскою, язык кошунственный) sounds.

The audio-emotional modality defines the image of beauty's perception, which is only obliquely revealed by means of the phrase "он вспомнить захотел". The specific philosophical insight of the poem is the associative connection "beauty - love". Beauty appears as the author-specific synonym of the universal triune idea, one of the parts of which is also true love. On earth, in the Mundane, it manifests as romantic attraction, as a longing for a perfect tender feeling. The metaphor-circumlocutions “Тоскуя, вспомнил он святую красоту” and “Былой любви пленительнье звуки" are closely connected in meaning and represent the author's figurative comprehension of the idea of an eternal and unquenchable divine principle in man, which is manifested through the ethical and aesthetic principle of existence.

CONCLUSION. Based on V. Solovyov's philosophy, one may assume that images of beauty not only play a significant role in his poetry, but that the lexical makeup of such images used by him will be accompanied by a semantic property that matches the poet's aesthetic and philosophical views. The lexeme kpacoma $(-b l,-y,-e)$ is used in Solovyov's poetry 12 times. The word's semantic shifts illustrate the nuances of meaning typical for the actualization of the philosophical idea of beauty, its semantic refinement that emphasizes the associative connections with its emanations.

The present analysis demonstrates the general properties of a lexico-semantic analysis of aesthetically significant philosophical images that play an important role in V. Solovyov's artistic worldview. The base units that define the figurative perception and depiction of the world form semantic fields and lexical rows of associatively connected words, through which the poet's linguistic picture is formed. Images with a photic, chromatic, emotional and auditory property represent the basis for an in-depth lexico-semantic analysis of the concept of Beauty in V. Solovyov's poetry. 


\title{
LIST OF REFERENCES
}

Kotrelev, N.V. (2005). Istoriya teksta kak kontinuum voleizyavleniya avtora: Vl. Solovyev. Nochnoye plavaniye: Iz «Romantsero» Geyne. [The history of the text as a continuum of the author's will: Vl. Solovyov. Night swimming: From "Romanzero" Heine]. Istoriko-filologicheskiy sbornik «Shipovnik»: K 60-letiyu Romana Davidovicha Timenchika. Moskva, 151-175.

Mochulsky, K. V. (2000).Vladimir Solovyev. [Vladimir Solovyev]. Vl. Solovyev: Pro et contra. Lichnost' i tvorchestvo Vladimira Solovyeva v otsenke russkikh mysliteley i issledovateley. Antologiya. T. I. SPb.: Izdatel'stvo Russkogo Khristianskogo gumanitarnogo instituta, 556-829.

Pild. L. (2007). Geyne v literaturnom dialoge K. Sluchevskogo i Vl. Solovyeva [Heine in the literary dialogue of K. Sluchevsky and Vl. Solovyov]. Na mezhe mezh Golosom i Ekhom. Sbornik statey v chest' Tat'yany Vladimirovny Tsiv'yan. Moskva: Novoye izdatel'stvo.

Solovyev, V. S. (1994). Chteniya o bogochelovechestve. Stat'i. Stikhotvoreniyaipoema. Iz «Trekhrazgovorov» [Readings on GodManhood. Articles. Poems and poem. From the Three Talks]. SPb., Khudozhestvennaya literature.

Solovyev, V. S. (1889). Krasota v prirode [Beauty in nature]. Voprosyfilosofiiipsikhologii. (1), 23 - 72.

Solovyev, V. S. (1890). Obshchiysmysliskusstva [The general meaning of art]. Voprosyfilosofiiipsikhologii. (5), $84-102$.

Solovyev, V. S. (1890). O liricheskoypoezii [On lyrical poetry]. Russkoyeobozreniye. (12), 626-654.

Solovyev, V. S. (1890). Pervyy shag k polozhitel'noyestetike [The first step toward positive aesthetics]. VestnikYevropy. (1), $294-$ 302.

Solovyev, V. S. (1877). Filosofskiyenachalatsel'nogoznaniya [The philosophical beginnings of holistic knowledge]. Zhurnal ministerstva narodnogo prosveshcheniya. (190), Mart 60-99. Aprel' 235-253, (191) Iyun' 199-233, (194) Noyabr' 1-32.

\section{For citation:}

Korycankova Simona (2019) SEMANTIC REALIZATION OF THE LEXEME "KPACOTA" IN THE SYSTEM OF V. SOLOVYOV'S POETRY. International Scientific-Pedagogical Organization of Philologists “WEST-EAST ” (ISPOP). Scientific Journal WEST-EAST. Vol 2/1 N1 (October, 2019). pp. 11-15. doi:

\section{Для цитирования:}

Корычанкова Симона (2019) СЕМАНТИЧЕСКАЯ РЕАЛИЗАЦИЯ ЛЕКСЕМЫ «КРАСОТА» В СИСТЕМЕ ПОЭТИЧЕСКОГО ТВОРЧЕСТВА В. СОЛОВЬЕВА // International Scientific-Pedagogical Organization of Philologists “ WESTEAST" (ISPOP) . Scientific Journal WEST-EAST. Vol 2/1 N1 (October, 2019). C. 11-15. doi:

Information about the author: Simona Korycankova - Assoc. Prof. PhDr. Mgr., Ph.D., Head Department of Russian Language and Literature, Faculty of Education, Masaryk University, Brno, Czech Republic

address: Porici9, Brno 603 00, Czech Republic

e-mail: korycankova@ped.muni.cz

Сведения об авторе: Симона Корычанкова (Брно, Чешская Республика) -Doc. PhDr. Mgr., Ph.D., Заведующая кафедрой русского языка и литературы, Кафедра русского языка и литературы, Педагогический факультет Университет им. Масарика Адрес: Porici 9, Brno 603 00, CzechRepublic

e-mail:korycankova@ped.muni.cz

Manuscript received: 05/25/2019 Accepted for publication: 09/23/2019

DOI:

\section{REPRESENTATIONS OF SUCCESS AND FAILURE IN RUSSIAN AND CZECH PHRASEOLOGY: WAYS OF EXPRESSING LIFE EPERIENCE}

\author{
Elena Seliverstova \\ Doctor of Philological Sciences, Professor \\ St. Petersburg State University \\ (St. Petersburg, Russia) \\ selena754@inbox.ru
}

\begin{abstract}
It is common for a person to hope for success and to note cases of an unsuccessful set of circumstances that influenced the outcome of the case. Speakers note success and failure in different spheres of life and use different nominations and cultural codes to verbalize such ideas. Appeal to the expressive means of different languages allows to discover common human (pan-Slavic) condensed meanings - "Luck is changeable" (Временем в горку, а временем в норку; Czech. Dnes tlusto, a zejtra pusto), "And we will be lucky someday" (Будет и нанашей улице праздник; Poteče kdys voda I namůj mlýn) "Luck is predetermined by heaven (God)" (Не всякому по Якову, а кому Бог даст; Bez Božího požehnání marné lidské namáhání) etc., and specific national ideas:"Luck is more important than beauty" (Не хитер парень, даудачлив; неказист, даталанен),"Good luck alone is not enough for well-being" (Счастье без ума дырявая с ума: где найдёшь, там сгубишь), etc.Czech paremias are peculiar in conveying the idea of luck to a person unworthy (Čím větší neřád, tím větší štěstí),), sustainability of luck for somebody (Koho Bůh miluje, toho $i$ král naděluje) etc.
\end{abstract}

Key words: luck, verbalizer, proverb, condensed meaning, stereotypical representations 